\title{
Human Resource Role In Work-Life Balance: A Case Of High Technology Knowledge Workers In Taiwan
}

\author{
Kuan-Chou Chen, Purdue University Calumet, USA \\ Denise M. Woods, Purdue University Calumet, USA \\ Lin Zhao, Purdue University Calumet, USA \\ Keh-Wen "Carin" Chuang, Purdue University North Central, USA
}

\begin{abstract}
This case involves the problems that young people in Taiwan are facing in high tech companies. Employees are spending many hours in their jobs and making high salaries as a result, but their social lives are suffering greatly. This paper examines the relationship between the work and social life of young Taiwanese workers in high tech firms. Although salaries and compensation packages are high, the social lives of these workers have diminished greatly. This study provides a comprehensive viewpoint from the perspective of an employee within the Human Resource department of one of these companies.
\end{abstract}

Keywords: Human Resources Management, Hi-Tech Industry, Work-Life Balance, Knowledge Worker, Taiwan.

\section{INTRODUCTION}

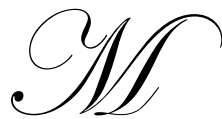

s. Jenny Liu is a Human Resource (HR) Specialist at the Tainan Research Park. She has a Bachelor's degree in Business with a concentration in Human Resources from a national university in Taiwan. She also has an M.B.A. from the same university. Ms. Liu found that she learned much about HR theory in her classes, at both the graduate and the undergraduate levels. Her undergraduate program prepared her to work in the field of Human Resource Management (HRM). This is a broad field that deals with managing people in work organizations. This includes acquiring, developing, and retaining satisfied and productive employees. Ms. Liu was interested in the field of HR because she enjoys dealing with people-oriented challenges. Her advisor, Dr. Yong Hong, told her that HRM professionals work with dynamic issues such as the changing employee attitudes about work, pay, and career goals. He also said that HRM professionals must insure that their employers comply with all applicable workplace laws related to hiring, testing, benefits, and safety, to name a few.

The undergraduate HR curriculum at the university provided Ms. Liu with a multidisciplinary approach to business that included coursework in key business areas. These include marketing, MIS, accounting, and finance in addition to her HR-specific courses. To major in HR, Ms. Liu was required to take ten HR courses at the undergraduate level. Additionally, she took three graduate level HR courses while completing her M.B.A. Ms. Liu took a variety of classes, including Labor Relations; Personnel Law; Benefits Administration; Compensation; and Managing Career Development. It is because of this last class that Ms. Liu is concerned with what she sees in the high tech field in which she works.

Ms. Liu studied hard and made excellent grades during her time at the university. However, she now finds that the HR theories that she learned in school do not necessarily apply to what she is experiencing in the real world. Basic HR principles taught at her university are not always relevant to the high tech industry. Employees in a high tech field are different than what she studied in her textbooks. Ms. Liu is concerned that she must take these differences into consideration as an HR Specialist. 


\section{TAINAN RESEARCH PARK}

Tainan Research Park (TRP) is located in a beautiful area of Tainan along the river. The company consists of five buildings, with no building older than five years. The setting of the park is not unlike the beautiful parks that you see in Taiwan with many trees, lovely flowers, and a pond stocked with fish and geese. Walking paths surround the grounds, and employees can enjoy walks during their lunch hours. The cafeteria has outdoor eating areas along the banks of the pond, so employees can dine and watch scenes of nature.

Tainan Research Park prides itself in hiring the best candidates from the best universities in Taiwan. The company is well-known and receives many more applications than what they need for any given job. Many students from top Taiwanese universities do internships at TRP while completing their studies. TRP therefore has a pool of potential job candidates at all times. This is especially true for engineering positions. The various engineering departments of the company hire qualified candidates from their intern pool together with highly qualified recent graduates of the Taiwan universities on a regular basis.

\section{R\&D Engineers At TRP}

Most Research and Development (R\&D) engineers at TRP have a high level of education. Company-wide, $65 \%$ of the engineers have Master's degrees, and $15 \%$ have Ph.D.s. This high level of education is required for the type of engineering design and development work that is required in the R\&D departments. Engineers at TRP are expected to design new products as well as make cost-effective enhancements to older products. In addition to education, TRP hires people who are creative and energetic. In an R\&D environment, creativity is key to successfully implementing new ideas in order to surpass the competition corporate-wide.

The average age of the engineers at TRP is 35, and most (i.e., 80\%) are not married. Although these are young people, gray hair and wrinkles make most of them look years older than their real age. Although they are highly compensated for their work, a high tech company work environment is quite stressful. This high compensation requires that the engineers work long hours. The TRP management also expects all engineers to contribute to the strategic goals of the company by recommending new products, in addition to their basic job functions. Because of this, the engineers are in high competition with each other to succeed.

\section{Knowledge Workers Without Social Life}

Because of the stress related to the engineering life at TRP, most company engineers have little or no social life. For the married engineers, the long hours negatively impact life with their families. Their spouses and children see little of the working engineer who is too tired to interact with them after spending many hours in his/her stressful work environment. This resulted, unfortunately, in many of the married engineers getting divorced. Their morale during and after their divorces was very low, which made them less effective in their jobs. Their creativity and their energy were both zapped as a result of poor home-life quality.

The single engineers also have poor social lives. Making friends at TRP during the work day is difficult because of the highly competitive nature of their jobs. They also find it difficult to make friends outside of work because of the long hours spent in their cubicles at TRP. Many single engineers therefore resort to going online (i.e., on the Internet) for new friends. There have been several cases lately of engineers who were swindled from contacts made on the Internet. Again, this resulted in low morale and a poor quality of life for the single engineers.

Additionally, this excessive work schedule environment has resulted in a high level of turnover at TRP. The current turnover rate at TRP is 65\%, versus the industry average of 30\% Engineers are leaving TRP to get away from the high competition and feel better about their own self-worth and work performance. Other reasons cited from engineers who recently left TRP is so that they could boost their already high salaries. As one exiting engineer put it, "As long as I have to work such excessive hours anyway, I may as well get paid even more so I can at least retire at a young age." 
The only response that TRP made to this mass engineer exodus was to give stock options to the most sought-after engineers to retain them. That seemed to plug the exodus hole for a short time. But then many of these engineers exercised those options with two years and left the company anyhow. That response by TRP, although lucrative for many engineers, was therefore not effective.

\section{Administration Problems}

One other significant problem plagued the engineering departments at TRP. Because of past salary increase practices, there is now a high salary gap between the engineer management levels and the engineering designers. For the same long working hours, those working in the operational levels (e.g., payroll, accounting, HR) made almost 15 times less than the engineering designers. These same operational level employees also made 25 times less than the engineering management groups.

Another problem that has arisen in the engineering management area is a general lack of qualified managers. Most of the engineering managers come from the ranks of engineering designers. They are highly qualified engineers, but they know nothing about management. They are also not given the skills through on-the-job training at TRP. This results in poor management techniques that add more to the low level of morale within the engineering departments.

\section{HUMAN RESOURCE INTERVENTION}

Jenny Liu, as a Human Resource Specialist at TRP, is quite concerned with the problems that she sees in the engineering departments. As she learned at her university, employees in organizations are viewed as essential resources, just as money and other things are resources that require management, in order for the organization to operate efficiently and effectively. Firms increasingly rely on the expertise of trained HRM professionals to help them develop and utilize people - their most valuable resources. In Ms. Liu's opinion, a primary duty of human resource professionals is to keep the organization staffed with the most qualified people available. TRP does an excellent job hiring qualified engineers. Another very important activity of any HR department is to perform administrative matters related to employment, including: promotions, training, compensation, benefits management, labor relations, and performance appraisal.

HR professionals also must plan for the strategic human resource needs of the organization. Employees are demanding more meaningful work assignments and more active roles in guiding the direction of their employers. It is up to the HR departments in most companies to provide long-term career plans for the employees of the company. Because of the volatile environment within TRP at this time, it is very difficult for Ms. Liu and the other HR specialists to do this aspect of their jobs.

\section{HR Issues}

Ms. Liu sees several issues resulting from the current TRP environment, but she questions what role the HR department can play in resolving these issues. She wonders how the HR department can help plot long-term plans for engineers whose morale is low or who are actively seeking employment elsewhere. She also wonders how to build a positive work environment to help retain the employees. Finally, Ms. Liu questions whether or not the HR department should be involved with the private family and home lives of the TRP employees. Is this truly an HR function, and if it is, how should one go about helping employees in this way?

The HR theories that Ms. Liu studied at the university provided excellent ideas on how to create a positive work environment. These theories, however, are difficult to apply in the negative engineering environment that has been created at TRP. 


\section{SUMMARY AND CONCLUSION}

R\& D engineers working in high tech companies in Tainan Research Park generally hold an advanced degree and make high salary, but they suffers a lot from long work hours and tedious social lives. This dilemma is raised and described from a HR specialist's point of view since she cannot find the answers from the textbooks or classes. This case strives to fill the gap between HR theories and unique features of the working practice in high tech companies.

Some other problems related to HRM are also presented, such as administrative and operational positions in these companies earn much less than engineers and most managers only have engineering background without any professional education in management. These could be the reasons to lead and worsen work-life struggle, low retention rate, and unfriendly working environment.

In summary, this case studies the problems of HRM in high tech companies in Taiwan and the potential reasons why the problems become serious in these companies by analyzing the characteristics of the employees, nature of their jobs, and the hierarchical structure of their management and administration team.

\section{DISCUSSION QUESTIONS}

1. Within the field of human resource management, is there a difference between supporting the high tech industry and a traditional manufacturing industry?

2. What role(s) does the Human Resource Management department have in balancing an employee's work life and home life in high tech companies, if any? Should they consider their high educational level, long working hours and high salary? What specific measures would you suggest to build a positive working environment?

3. What would you suggest to help the company administrators solve the pay discrepancy issue and the problem with the management skill development of highly qualified engineers?

\section{AUTHOR INFORMATION}

Kuan C. Chen, Ph.D. is Head of Department Information Systems in the School of Management at Purdue University Calumet in Hammond, Indiana. Dr. Chen has extensive experience in MIS research topics. He has authored numerous journal papers on topics varying from project management to Information Technology (IT) economics. He has also been a contributing author on several books and a technical editor on numerous books and journal articles. Dr. Chen maintains an active Web development and database consulting practice in both the U.S. and Taiwan. He has a Ph.D. in MIS and another Ph.D. in Economics, both from Michigan State University.

Denise M. Woods, Ph.D. is an Associate Professor at Purdue University Calumet. She teaches basic MIS together with courses in Systems Analysis and Design, Knowledge and Decision Support Management, and graduate level MIS courses. Dr. Woods has a Ph.D. from Purdue University. Prior to starting her career in higher education, Dr. Woods worked for 20 years in industry where she was the manager of software and Web development. In addition to this, Dr. Woods has written numerous books about Web development and HTML.

Lin Zhao, Ph.D. is an Assistant Professor of Information Systems in the School of Management at Purdue University Calumet. Her research focuses on Human-Computer Interaction (HCI) and business decision making. Her teaching interests include principles of information systems, system analysis \& design, system development, database management, business intelligence, and E-business strategies. She received her Ph.D. in Management Information Systems from Case Western Reserve University in 2008. Before joining Purdue University Calumet, Dr. Zhao taught one year in the Department of Computer and Information Science at Arkansas Tech University. 
Keh-Wen (Carin) Chuang, MS. is an Assistant Professor in the Department of Computer \& Information Technology at Purdue University North Central. Before entering academia, Professor Chuang has been spent over 12 years of professional experience in database administration and information system development for three Fortune 100 companies in Illinois, Indiana and Michigan. Professor Chuang is a certified JAVA developer, SQL Server Administrator and E-Commerce Web Site Developer. Professor Chuang earned her two Master degrees in Information Systems and Urban Studies at Michigan State University, and her BBA in International Economics from Soochow University at Taiwan.

\section{REFERENCES}

1. (2004). EBRI 2004 Retirement Confidence Study, from www.ebri.org

2. (2006). 10 tips on writing the living Web. A Strong Benefits Mix May Be Answer to Recruiting, Retention Woes. from www.workindex.com

3. (2006). Cost Control Is Shifting to a Long-Term View. HR Focus, 1.

4. (2006). Few Employees Understand and Appreciate Their Total Compensation Package. from www.Charltonconsulting.com

5. (2006). Incorporate "Employer of Choice" Coals into Strategic, Benefits Planning. Best Practices in HR, 3.

6. (2006). More Firms Adopting Consumerism. from www.employeebenefitnews.com

7. (2006). Two-Thirds of Large Employers Now Offering Incentives to Improve Employees' Health. From www.barometersurveys.com

8. (2007). Insured Americans Accept Rising Health Care Costs-But Are Not Prepared for Them. Retrieved April 20, 2007, from www.worldatwork.org

9. Ackley, D. Communication: The Key to Putting the Benefit Back in Benefits. Workspan, 31-34.

10. An Executive Perspective on Employee Benefits. (2006). from www.mckinseyquarterly.com

11. Arizona Governing Committee v. Norris, 103S., 32FEP Case 233 (3492 1983).

12. $\quad$ Around the Benefits World. Employee Benefit News, 35-36.

13. Bianchi, A. J. Futurecast: Cash Balance Retirement Plans After Cooper v. IBM. Employee Benefit News, 72.

14. Bolch, M. (March 2006). Bearing Fruit. HR Magazine, 57-60.

15. Breeden, R. (2006). Firms Consider End to Employee Health Insurance. The Wall Street Journal.

16. Carlson, L. Surveys Show Fewer Vacation Days Taken, Offered. Employee Benefit News, 20.

17. Choice Offsets Cost for FedEx Workers. from www.workforce.com

18. Costo, S. L. Trends in Retirement Plan Coverage over the Lake Decade. Monthly Labor Review, 58-64.

19. Davidson, J. F.-E. a. B. How to Measure Human Resources Management (3rd ed.).

20. Demby, E. R. (2003, August 2003). Nothing Partial About These Benefits. HR Magazine, 72-81.

21. Drucker, P. (1999). Management Challenges for the 21st Century. New York: HarperCollins.

22. Dunkelberger, D. Avoiding COBRA's Bite: Three Keys to Compliance. Compensation and Benefits Review, 44.

23. Elswick, J. (2005). Loaded Statements: Web-Based Total Compensation Statements Keep Employees in the Know, from www.benefitnews.com

24. Faulkner, G. Absent and Accounted For. Human Resource Executive, 56-57.

25. Francis, E. E. S. a. T. What You Need to Know About Pension Changes. The Wall Street Journal, D1.

26. Hirschman, C. (February, 2006). Emploees Choice. HR Magazine, 95.

27. Hoffman, B. G. (2005). Ford to Freeze Health Plans. The Denver Post, 3C.

28. Jr., A. L. H. a. T. M. B. (2003). Tax Relief Through Cafeteria Plans and Flexible

29. Klett, T. Challenges Loom from California's Paid Family Leave. Employee Benefit News, 35.

30. Koski, R. D. K. a. R. The Roth 401(K). Workspan, 36.

31. L. C. (2006). Enrollment in New CDHPs Remains Low, from www.employeebenefitnews.com

32. Lee, K. Study Shows Six Out of Ten Companies Outsource Benefits. Employee Benefit News, 11.

33. Lieber, R. The Next Frontier: Paternity Leave. The Wall Street Journal, B1.

34. Lisanti, L. (2006). Happy Employees, Happy Customers. Convenience Store News, 97.

35. Maas, A. Legal Transformation. Employee Benefit News, 27.

36. Markowich, M. M. (2007). Paid Time-Off Banks. WorldatWork. 
37. Meister, A. A Matter of Degrees. Workforce Management, 32-38.

38. Michal Kisilevitz, S. D., Daniel Metz. (2006). Improving Employee Benefits Through Effective Communication. WorldatWork Journal, First Quarter, 52-60.

39. Miller, S. (2006). Alternative Benefit Strategies: Not Whether But Which, 2006, from www.shrm.org/rewards

40. Munoz, S. S. A Good Idea, But... The Wall Street Journal, R6.

41. Neeleman, S. Making Health Savings Accounts Work. Compensation and Benefits Review, 33.

42. Nownes, J. What Every Plan Administrator Needs to Know About QDROs. HRAM Highlights, 8.

43. Pilzner, A. M. Pension Protection Act of 2006: Mandates and Options for Retirement Plans. SHRM HR Legal Report, $1+$.

44. Powell, D. Reporting and Disclosure Requirements Under the Pension Protection Act of 2006. Employee Benefit News, 52.

45. Reagan Baughman, D. D., and Douglas Holtz-Eakin. (2003). Productivety and Wage Effects of "Family Friendly" Fringe Benefits. International Journal of Management, 24, 247.

46. Rosenbloom, J. S. The Handbook of Emploee Benefits: Design, Funding, and Administration (6th ed.).

47. Separate and Unequal: The Effect of Unequal Access to Employment-Based Health Insurance on Same-Sex and Unmarried Different-Sex Couples. Contemporary Economic Polocy, 24, 582.

48. Silva, C. Employers Turn to Mini-Med Plans as Stop Gaps. Employee Benefit News, 39.

49. Simon, J. (2003). Weighing the Cost of Emploee Benefits. Workspan, 56-57.

50. Smerd, J. (2007). You Can Do Anything But Don't Mess My Health Insurance, from www.workforce.com

51. $\quad$ Spending Accounts. Journal of Financial Services Professionals, 57, 14.

52. Too Many Workers Take Advantage of Sick Days. Retrieved October 31, 2006, from www.benefitnews.com

53. Wells, S. J. (December 2006). Will Employees Orchestrate Their Own Health Care? HR Magazine, 62-67. 